\title{
Cultura Cultura
}

Vol. 32 | 2013

O surgimento da ciência moderna na Europa

\section{Siglas utilizadas}

\section{(2) OpenEdition \\ 1 Journals}

\section{Edição electrónica}

URL: http://journals.openedition.org/cultura/1939

DOI: $10.4000 /$ cultura. 1939

ISSN: 2183-2021

\section{Editora}

Centro de História da Cultura

\section{Edição impressa}

Data de publição: 2 dezembro 2013

ISSN: 0870-4546

\section{Refêrencia eletrónica}

"Siglas utilizadas », Cultura [Online], Vol. 32 | 2013, posto online no dia 18 maio 2015, consultado a 22 setembro 2020. URL : http://journals.openedition.org/cultura/1939; DOI : https://doi.org/10.4000/ cultura.1939

Este documento foi criado de forma automática no dia 22 setembro 2020.

(c) CHAM - Centro de Humanidades / Centre for the Humanities 


\section{Siglas utilizadas}

1 A: G. W. Leibniz, Sämtliche Schriften und Briefe, Herausgegeben von der Deutschen Akademie der Wissenschaften zu Berlin, Darmstadt, 1923 ss, Leipzig, 1938 ss, Berlin, 1950 ss. A citação será feita por série, volume, página.

2 AT: Oeuvres de Descartes, ed. Ch. Adam et P. Tannery, Paris, 1897-1909: reed. VrinC.N.R.S., 11 vols, 1964-1974.

3 C: Couturat, L. (ed.): Opuscules et fragments inédits de Leibniz. París. Alcan, 1903; reimpr. Hildesheim, G. Olms, 1966.

4 Dutens: G. G. Leibnitii Opera Omnia, ed. L. Dutens, 6 vols, Ginebra, 1768; reimpr. Hildesheim, Olms, 1989.

5 GM: G. W. Leibniz, Mathematische Schriften, ed. C.I. Gerhardt, 7 vols., Berlín, 1848-63; reimp. Hildesheim, G. Olms ,1962.

6 GP: G. W. Leibniz, Die philosophischen Schriften, ed. C. I. Gerhardt, 7 vols, Berlin, 1857-1890; reimp. Hildesheim, Olms, 1960-1965.

7 Lamarra: G. W. Leibniz, Essais scientifiques et philophiques. Les articles publiés dans les journaux savants, eds.A. Lamarra, R. Palaia, 3 vols., Hildesheim, Olms, 2005.

8 OCF: G. W. Leibniz, Obras filosóficas y cientificas, coord. Juan Antonio Nicolás, Granada, Comares, 2007ss. 